\title{
The Influence of Timber Types, Assortments, Qualities, Cuttings, Timber Tracts, Prices, Places, and Marketing Expenses on Timber Sales Volumes
}

\author{
Taufik Rochmanto ${ }^{* 1}$, Gadang Ramantoko ${ }^{* 2}$, Indira Rachmawati ${ }^{* 3}$ \\ ${ }^{\#}$ Faculty of Economics and Business, Telkom University \\ Jl. Gegerkalong Hilir No. 47, Bandung 40152
}

\begin{abstract}
The timber industry is one source of state revenue that plays an essential role in the forestry sector. However, this sector only grew by $3.66 \%$ in the Q4 of 2019, compared to the same period in 2018 by $4.25 \%$. Timber sales also decreased by $5.6 \%$ due to several factors such as price adjustments, timber availability, and the quality level of the timber sold. This research aims to analyze the influence of the 4Ps of Marketing, namely products and their attributes in timber type, assortment, quality, cutting, timber tract, price, place, and marketing expenses on timber sales volume in July December 2019. This research uses secondary data, which are processed using the multiple regression analysis methods. The results of this study indicate that the type of timber (X1), assortment (X2), quality (X3), cutting (X4), timber tract (X5), and price (X6) partially have a significant effect on timber sales volume (Y). Meanwhile, place (X7) and marketing expenses (X8) partially have no significant impact on the timber sales volume (Y). However, simultaneously all these variables have a significant effect on the timber sales volume $(Y)$.
\end{abstract}

Keywords: 4Ps of marketing, sales volume, multiple linear regression, timber

\section{INTRODUCTION}

The forestry sector is one of the businesses that provide considerable profits for a company and a country. One of the forestry sub-sectors that provide benefits is the level of timber productivity. Many sub-sectors can generate profits in this sector, including timber products, the tourism industry, etc. PT X is one of the StateOwned Enterprises (SOE) engaged in the Indonesian forestry industry. PT.X must play three functions at once, namely economic, social, and ecological processes ${ }^{[5]}$.

Timber sales make the most important reference for decisions of forest district managers. Apart from the Forest Fund's redistributive role, revenues from timber sales determine district budgets. Therefore, this is an opportunity to attract foresters' maximize these revenues ${ }^{[12]}$.

The future success of the timber products industry depends entirely on progressively-minded entrepreneurs with customer-oriented management skills ${ }^{[20]}$. Companies must continuously adapt to changing trends and manage factors that affect the sales volume of timber products produced both externally and internally. In 2019, timber sales decreased by $5.6 \%$ due to several factors, such as price adjustment, timber availability, and the quality of the timber for sale. It can be seen from the total export value of Indonesia's processed wood in 2019 of US\$ 11.64 billion, slightly declined 4\% from the export value of 2018 of US\$12.13 billion ${ }^{\text {[28] }}$. Meanwhile, industrial timber production in 2019 increased by $10.48 \%$, where the planting rate also increased by $23.97 \%$.

The background above becomes the reference when the planting conditions are higher than income. The decline in sales volume during 2019 made the author interested in examining whether factors, especially products and their attributes (quality), significantly affect sales volume, considering that many of the timber quality did not meet expectations. The author will combine it into the marketing mix (4p); product, price, place, and promotion. This study aims to determine the effect of timber type, timber quality, timber sorting, timber felling, timber tract, timber price, place of purchase, and expenses in marketing on timber sales volume. 
DOI: $\underline{10.51386 / 25815946 / i j s m s-v 4 i 4 p 114}$

\section{LITERATURE REVIEW}

\section{A. Marketing}

Marketing is the activity, set of institutions, and processes for creating, communicating, delivering, and exchanging offerings that have value for customers, clients, partners, and society at large ${ }^{[8]}$. For this reason, the basic concept of marketing itself can be a relationship between sellers and buyers to meet human needs, and human wants. However, the implementation is not easy ${ }^{[1]}$.

\section{B. Marketing 4Ps}

A marketing mix is a set of tools that marketers can use to shape the characteristics of the services offered to customers. These tools can use to develop long-term strategies and also to design short-term tactical programs $^{[25]}$. In marketing, It can carry out planning activities through four components: product, price, promotion, and distribution channel ${ }^{[11]}$. In this research, the author wants to know how much influence 4Ps marketing mix wood sales volume.

\section{Sales Volume}

Sales volume is the level of sales obtained by the company for a certain period in units (units/total/rupiah) ${ }^{[19]}$. Sales volume is an achievement expressed quantitatively in terms of physical or volume or units of a product ${ }^{[18]}$. Sales volume analysis is an in-depth study of the net sales of a company's income statement or operating report. Management needs to analyze the total sales volume as well as the volume itself ${ }^{[24]}$.

\section{Timber Price}

Timber prices are essential for forest management optimization. Hence analysis of historical price series is an important tool supporting investment and harvest decisions to maximize benefits from price fluctuations ${ }^{[9][10]}$. In this study, the reference is used to study the Price of wood-based quality. For example, the Price of teak wood per- $\mathrm{m}^{3}$ of A1-A4 quality is around Rp. 2 million - Rp. 8 million

\section{E. Timber}

Wood is a natural resource that is renewable and available in various species in tropical countries ${ }^{[21]}$. The use of timber as a supporting construction has become an alternative to iron and reinforced concrete. On average, timber construction with the same bearing capacity has a lower price of $25 \%-40 \%$ than steel and reinforced concrete construction ${ }^{[26]}$. The types of wood included in the sales research are Teak, Rosewood, Mahogany, Kauri, Pinewood, Auri, Acacias, Silk tree, Burflower, Rasamala, Beechwood, and black-wood cassia.

\section{E. Assortment}

Assortment results from a sawing process whose length, width, and thickness are by its intended use ${ }^{[15]}$. Assortment becomes one of these research variables is because the author wants to examine how significant assortment with a specific size affects timber sales volume.

\section{F. Timber Quality}

Quality is a factor in an item by the purpose for which they are needed ${ }^{[2]}$. Timber quality, in general, can be defined as a measure of the characteristics that affect the properties of products made from that timber. A more precise definition of quality may be challenging to understand because the essential properties of the wood used for a product are often different from the crucial properties of other products ${ }^{[26]}$.

\section{G. Cutting}

In teak plantation concessions in the research area, there are various types of cutting, namely final cutting (cutting A, B, and C), clearance cutting, maintenance cutting (cutting D1), unexpected cutting (cutting D2), and thinning (cutting E). The types of mainly cutting carried out are final cutting and thinning ${ }^{[4]}$.

\section{H. Timber Tract}

Timber tracts are wood bundling in one land area, which can be in one length class, one diameter class, one quality. It aims to potential buyers can easily find the wood they want based on one class similarity. Potential buyers can buy based on tracts' data during the purchase process, including the desired volume. So that the buyer can be search based on separation in the form of plots will be seen the class and quality of each timber tract. Timber sold and ready to be picked up marked with a seller mark as a sign that the wood is legal and given a certificate of legitimate forest products ${ }^{[27]}$. 
DOI: $\underline{10.51386 / 25815946 / \mathrm{ijsms}-\mathrm{v} 4 \mathrm{i} 4 \mathrm{p} 114}$

\section{Place}

Choosing a good location is a crucial decision. First, the location decision has a permanent and long-term impact, whether the place is purchased or just leased. Second, location will affect business growth in the future. The location chosen must be able to experience economic growth so that the business can survive. And lastly, if the value of the place deteriorates due to environmental changes that can occur at any time, perhaps the company must be moved or closed ${ }^{[3]}$.

\section{J. Marketing Expenses}

Marketing expenses can be interpreted as costs or some sacrifices borne by the company in carrying out marketing activities, especially in implementing promotions. Promotion costs are economic sacrifices borne by companies to carry out their advertisements ${ }^{[18]}$.

With an explanation related to the variables that will use above, the following is a hypothesis:

H1: The type of timber has a positive and significant effect on the volume of timber sales.

$\mathrm{H} 2$ : Assortment has a positive and significant effect on the volume of timber sales.

H3: Timber quality has a positive and significant effect on timber sales volume.

H4: Cutting has a positive and significant effect on the volume of timber sales

H5: Timber tract has a positive and significant effect on the volume of timber sales

H6: Price has a significant positive effect on the volume of timber sales.

H7: Place has a significant positive effect on the volume of timber sales.

H8: Marketing Expenses have a positive and significant effect on the volume of timber sales

\section{III.METHODOLOGY}

This research is causal, aiming to determine the effect of independent variables, namely timber type, assortment, timber quality, cutting, and timber tract, and price on timber sales volume as a dependent variable.

The setting of this research is non-contrived. Non-contrived research settings are conducting in normal environmental conditions that usually occur or are natural ${ }^{[7] . ~ T h e ~ e x e c u t i o n ~ t i m e ~ i n ~ t h i s ~ s t u d y ~ w a s ~ c r o s s-~}$ sectional. Cross-sectional research involves collecting data from a population in one period, then the data is processed, analyzed, and then conclusions are drawn ${ }^{[7]}$.

The sample selection was taken based on the purposive sampling method. The criteria for the companies considered as the sample in this study are companies that have complete variable data (timber type, assortment, quality, cutting, timber tract, price, place, marketing expenses, and timber sales volume). The data studied were sourced from secondary data (historical transaction data) as much as 3118 data. The analysis technique used is multiple linear regression.

Multiple linear regression equations are used to find out or get a picture of the effect of the independent variable on the dependent variable ${ }^{[22]}$. This study has eight independent variables, namely product and attributes (such as timber type, assortment, quality, cutting, and timber tract), price, place, and marketing expenses. The following is model adopted from the model equation from previous research where multiple linear regression analysis equations for eight predictors refers to the formula proposed by Sugiyono ${ }^{[22] ~: ~}$

$$
Y=\alpha+\beta 1 X 1+\beta 2 X 2+\beta 3 X 3+\beta 4 X 4+\beta 5 X 5+\beta 6 X 6+\beta 7 X 7+\beta 8 X 8+e
$$

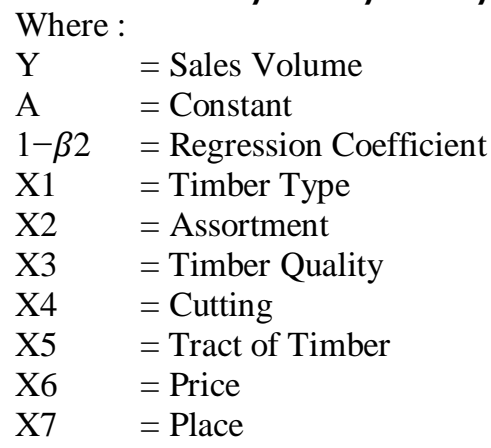


DOI: $\underline{10.51386 / 25815946 / \mathrm{ijsms}-\mathrm{v} 4 \mathrm{i} 4 \mathrm{p} 114}$

Volume: 4 Issue: 4

X8 $=$ Marketing Expenses

$\mathrm{e} \quad=$ Error

\section{IV.RESULTS}

In this study, multiple linear regression analyses are intended to determine the product and its attributes such as the influence of Timber Type (X1), Assortment (X2), Quality (X3), Cutting (X4), Timber tract (X5), Price per m3 (X6), Selling Place/Places (X7), and Marketing Expenses (X8) on Sales Volume (Y). This research aims to predict or estimate the value of the dependent variable in a causal relationship to the value of other variables.

Before analyzing the regression model, the classical assumption is first tested so that the model formed provides a BLUE estimate (Best, Linear, Unbiased, Estimator). By using the SPSS software v. 21 program, the following normality test result:

This assumption test consists of three tests: normality test, heteroscedasticity test, and multicollinearity test ${ }^{[22]}$. By using the SPSS software v. 21 program, the following normality test result:

Table 1. Result of Kolmogorov-Smirnov Test

One-Sample Kolmogorov-Smirnov Test

\begin{tabular}{|ll|r|}
\hline & & \multicolumn{1}{|c|}{ Unstandardized Residual } \\
\hline $\mathrm{N}$ & Mean & 3118 \\
Normal Parameters & & .0000000 \\
& Std. Deviation & 1.86003453 \\
& Absolute & .133 \\
Most Extreme Differences & Positive & .133 \\
& Negative & -.096 \\
Kolmogorov-Smirnov Z & & 7.451 \\
Asymp. Sig. (2-tailed) & & .000 \\
\hline
\end{tabular}

a. Test distribution is Normal.

b. Calculated from data.

Based on the SPSS output above, the Sig value was obtained from the normality test using the KolmogorovSmirnov method of 0.000 . Because the p-value is smaller than alpha $(0.000<0.05)$, it concluded that the residual data is not normal. Because the data used is data in a large number of observations. Meanwhile, the normality of the data is assumed to be fulfilled because the panel data has more than 30 observations. The result follows the central limit theorem, which states that if $\mathbf{n}$ is more than 30 , it is stated that the data has a normal tendency ${ }^{[16]}$. Based on this theorem, further testing can continue.

A good regression model is one with homoscedasticity or no heteroscedasticity. The heteroscedasticity test aims to test whether there is an inequality of variance in the regression model from the residual of one observation to another observation ${ }^{[22]}$. One of the methods used to detect the presence or absence of heteroscedasticity is to look at the graph plot between the predicted values of the dependent variable, namely ZPRED, with the residual SRESID. 


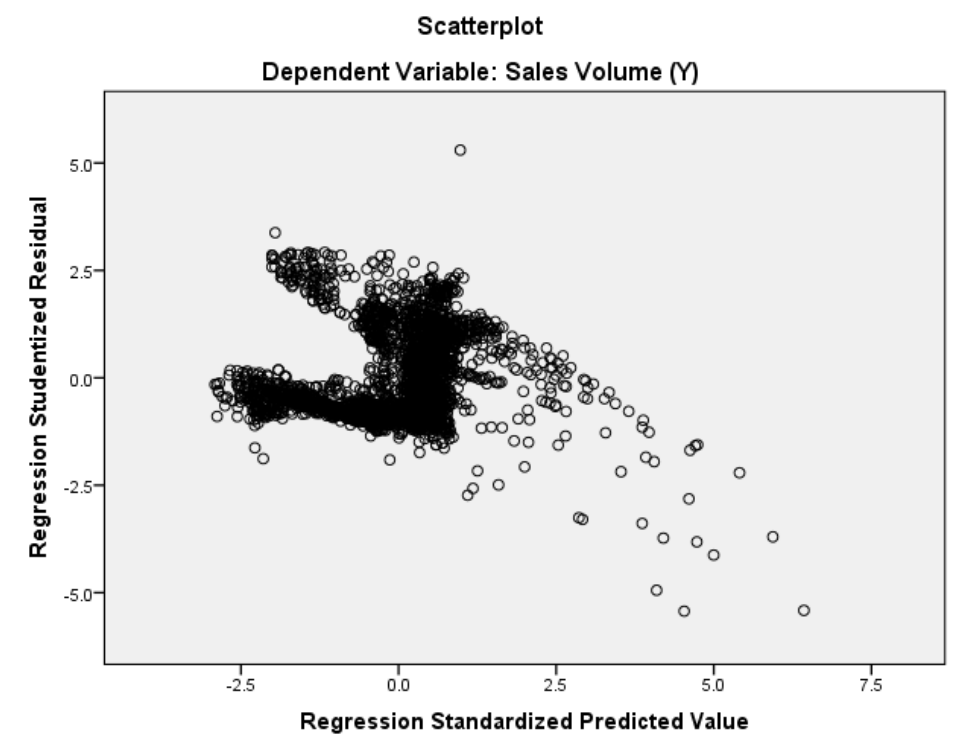

Fig 1. Scatterplot of Heteroscedasticity test

The scatterplot above represents the dots spread randomly, not forming a pattern. The points spread both above and below zero on the Y-axis. It can be concluded that there is no heteroscedasticity in the regression model, so the regression model is feasible to use for subsequent analysis.

The multicollinearity test aims to test whether there is a correlation between the independent variables in the model. A good model should not correlate with the independent variables. Following is the output VIF value for each independent variable.

Table 2. Result of Multicollinearity Test

\begin{tabular}{|c|c|c|c|}
\hline \multicolumn{2}{|c|}{ Model } & \multicolumn{2}{|c|}{ Collinearity Statistics } \\
\hline & & Tolerance & VIF \\
\hline \multirow{9}{*}{1} & (Constant) & & \\
\hline & Timber Type (X1) & .871 & 1.148 \\
\hline & Assortment (X2) & .718 & 1.392 \\
\hline & Quality (X3) & .785 & 1.275 \\
\hline & Cutting (X4) & .962 & 1.040 \\
\hline & Timber Tract (X5) & .945 & 1.058 \\
\hline & Price (X6) & .676 & 1.480 \\
\hline & Place (X7) & .995 & 1.005 \\
\hline & Marketing Expenses (X8) & .987 & 1.013 \\
\hline
\end{tabular}

The results above show that the VIF value of each independent variable is below 10, Timber Type $(\mathrm{X} 1)=$ 1.148, Assortment $(X 2)=1.392$, Quality $(X 3)=1.275$, Cutting $(X 4)=1,040$, Timber Tract $(X 5)=1.058$, Price $(\mathrm{X} 6)=1.480$, Place $(\mathrm{X} 7)=1.005$, and Marketing Expenses $(\mathrm{X} 8)=1.013$. Based on these results, it can be concluded that there is no multicollinearity between independent variables in the model. 
DOI: $\underline{10.51386 / 25815946 / \mathrm{ijsms}-\mathrm{v} 4 \mathrm{i} 4 \mathrm{p} 114}$

Volume: 4 Issue: 4

July to August 2021

https://www.ijjsmsjournal.org

Table 3. Coefficient Value Calculation Results of Multiple Linear Regression Equation

\begin{tabular}{|c|c|c|c|c|c|c|}
\hline \multirow{2}{*}{\multicolumn{2}{|c|}{ Model }} & \multicolumn{2}{|c|}{$\begin{array}{c}\text { Unstandardized } \\
\text { Coefficients } \\
\end{array}$} & \multirow{2}{*}{$\begin{array}{c}\text { Standardized } \\
\text { Coefficients } \\
\text { Beta }\end{array}$} & \multirow[t]{2}{*}{$\mathrm{t}$} & \multirow[t]{2}{*}{ Sig. } \\
\hline & & B & Std. Error & & & \\
\hline \multirow{9}{*}{1} & (Constant) & 7.121 & 9.686 & & .735 & .462 \\
\hline & Timber Type (X1) & .433 & .011 & .529 & 38.869 & .000 \\
\hline & Assortment (X2) & .078 & .036 & .032 & 2.142 & .032 \\
\hline & Timber Quality (X3) & .208 & .030 & .100 & 6.995 & .000 \\
\hline & Cutting (X4) & .052 & .014 & .048 & 3.691 & .000 \\
\hline & Timber Tract (X5) & .000 & .000 & .342 & 26.167 & .000 \\
\hline & Price (X6) & .267 & .046 & .089 & 5.744 & .000 \\
\hline & Place(X7) & .014 & .046 & .004 & .312 & .755 \\
\hline & $\begin{array}{l}\text { Marketing Expenses } \\
\text { (X8) }\end{array}$ & .016 & .604 & .000 & .026 & .979 \\
\hline
\end{tabular}

a. Dependent Variable: Sales Volume (Y)

The outputs above show the value of the constant and the regression coefficient, so the moderating regression equation can be formed as follows:

$\mathrm{Y}=7.121+0.433 \mathrm{X} 1+0.078 \mathrm{X} 2+0.208 \mathrm{X} 3+0.052 \mathrm{X} 4+0.000356 \mathrm{X} 5+0.267 \mathrm{X} 6+0,014 \mathrm{X} 7+0.016 \mathrm{X} 8$

The above equation can be interpreted as follows:

$\alpha=7.121$ means that if the type of timber (X1), assortment (X2), quality (X3), cutting (X4), timber tract (X5), price (X6), place (X7), marketing expenses (X8) is zero (0), sales volume (Y) will be 7.121 units;

$\beta 1=0.433$ means that if the type of timber is getting better one level and the other variables are constant, then the sales volume (Y) will increase by 0.433 units;

$\beta 2=0.078$ means that if the Assortment is getting higher one level and the other variables are constant, then the sales volume $(\mathrm{Y})$ will increase by 0.078 units.

$\beta 3=0.208$ means that if the quality is getting better one level and the other variables are constant, then the sales volume (Y) will increase by 0.208 units;

$\beta 4=0.052$ means that if the cutting has increased by one unit and other variables are constant, then the sales volume (Y) will increase by 0.052 units;

$\beta 5=0.000356$ means that if the timber tract increases by one unit and other variables are constant, then the sales volume (Y) will increase by 0.000356 units;

$\beta 6=0.267$ means that if the price increases by one unit and other variables are constant, then the sales volume (Y) will increase by 0.267 units;

$\beta 7=0,014$ means that if the place is getting better and other variables are constant,sales volume (Y) will increase by 0,014 units;

$\beta 8=0.016$ means that if marketing expenses have increased by one unit and other variables are constant, then the sales volume (Y) will increase by 0.016 units. 
Table 4. Model Summary

Model Summary
\begin{tabular}{|l|r|r|r|c|}
\hline Model & R & R Square & $\begin{array}{c}\text { Adjusted R } \\
\text { Square }\end{array}$ & $\begin{array}{c}\text { Std. Error of the } \\
\text { Estimate }\end{array}$ \\
\hline 1 & $.706^{\mathrm{a}}$ & .499 & .498 & 1.86243 \\
\hline
\end{tabular}

a. Predictors: $\quad$ (Constant), Marketing Expenses (X8), Price (X6), Place(X7), Cutting (X4), Timber tract (X5), Quality (X3), Timber Type (X1), Assortment (X2)

b. Dependent Variable: Sales Volume (Y)

Based on the results of the correlation calculation, it is known that the correlation coefficient of 0.706 indicates a strong relationship between the independent variables and the dependent variable simultaneously.

Based on the coefficient of determination analysis, the coefficient of determination value is $49.9 \%$ which means that the influence of Timber Type (X1), Assortment (X2), Quality (X3), Cutting (X4), Timber tract (X5), Price per m3 (X6), Places (X7), Marketing Expenses (X8) as much as 49.9\% on Sales Volume (Y). In contrast, the remaining $50,1 \%$ is influenced by non-observed factors in this study.

Table 5. Simultaneous Hypothesis Testing (F-Test)

\begin{tabular}{|rl|r|r|r|r|r|}
\hline \multicolumn{1}{|c|}{ Model } & & Sum of Squares & \multicolumn{1}{c|}{ df } & Mean Square & \multicolumn{1}{c|}{ F } & \multicolumn{1}{c|}{ Sig. } \\
\hline \multirow{2}{*}{1} & Regression & 10741.824 & 8 & 1342.728 & 387.106 & $.000^{\mathrm{b}}$ \\
& Residual & 10783.974 & 3109 & 3.469 & & \\
& Total & 21525.798 & 3117 & & & \\
\hline
\end{tabular}

a. Dependent Variable: Sales Volume (Y)

b. Predictors: (Constant), Marketing Expenses (X8), Price (X6), Place(X7), Cutting (X4), Timber Tract

(X5), Quality (X3), Timber Type (X1), Assortment (X2)

The simultaneous hypothesis testing (F-Test) resulted in a p-value (sig) of 0.000 . Because the p-value $<0.05$ so the H0 is rejected. It means that the Timber Type (X1), Assortment (X2), Quality (X3), Cutting (X4), Timber Tract (X5), Price (X6), Place (X7), and Marketing Expenses (X8) have a significant simultaneous effect on sales volume (Y).

According to Table 3, the first one is about the influence of Timber Type (X1) on Sales Volume (Y). It can be seen that the p-value is 0.000 from the above calculation. Because the p-value $<0.05$ or $0.000<0.05$, then $\mathrm{H} 0$ is rejected and $\mathrm{H} 1$ is accepted. It means that Timber Type (X1) has a significant effect on Sales Volume (Y). The second one is about the effect of Assortment (X2) on Sales Volume (Y). The p-value generated is smaller than 0.05 or $0.032<0,05$, then $\mathrm{H} 0$ is rejected and $\mathrm{H} 1$ is accepted. It means that Assortment (X2) has a significant effect on Sales Volume (Y). Furthermore for next relationship, Quality (X2) has a significant effect on Sales Volume (Y) Because the p-value $<0.05$ or $0.000<0.05$, then $\mathrm{H} 0$ is rejected and H1 is accepted. A cutting (X4) has a significant effect on Sales Volume (Y) because the p-value is smaller than 0.05 or $0.006<0.05$, then $\mathrm{H} 0$ is rejected, and H1 is accepted. The Timber tract (X5) has a significant effect on Sales Volume (Y) because the pvalue is smaller than 0.05 or $0.000<0.05$, then $\mathrm{H} 0$ is rejected, and $\mathrm{H} 1$ is accepted. The next one, Timber Price (X6), has a significant effect on Sales Volume (Y) because the p-value is smaller than 0.05 or $0.000<0.05$, then $\mathrm{H} 0$ is rejected, and $\mathrm{H} 1$ is accepted. Place (X7) has no significant influence on Sales Volume (Y) because the p-value is greater than 0.05 or $0.755>0.05$, then $\mathrm{H} 0$ is accepted, and $\mathrm{H} 1$ is rejected. The last one, Marketing Expenses (X8), has no significant effect on Sales Volume (Y) because the p-value is greater than 0.05 or $0.979>0.05$, then $\mathrm{H} 0$ is accepted, and $\mathrm{H} 1$ is rejected. 
DOI: $10.51386 / 25815946 / \mathrm{ijsms-v4i4p114}$

Volume: 4 Issue: 4

July to August 2021

https://www.ijsmsjournal.org

The place is said to have no significant effect on sales volume due to the customers are willing to buy products directly to the timber picking place, located close to the timber harvesting site. Therefore, the place and distance factors are not a big problem for buyers because they need the product. They are willing to sacrifice to take the product for satisfaction.

For the advice given by the author regarding place, namely to expand the sales network by adding places where timber is taken, to make it easier for buyers to reach areas. Although, in this case, buyers are willing to reaching out to sites that are a bit far away. Meanwhile, marketing expenses have no significant effect because PT X is less concerned about marketing. Due to the habit of potential customers who prefer to buy directly or even their mobile phones still do not support install applications.

For the future, the author's advice that some improvements are needed, such as expanding advertisements not only through online media but also utilizing offline media, such as community education and placing advertisements through billboards in strategic locations massively and in addition, maintaining with existing buyers and establishing relationships with new buyers.

\section{Conclusions}

Partially, Timber Type (X1), Assortment (X2), Quality (X3), Cutting (X4), Timber Tract (X5), Price (X6) significantly influences sales volume. Meanwhile, Place (X7) and Marketing Expenses (X8) partially have no influence on sales volume. Simultaneously, Timber Type (X1), Assortment (X2), Quality (X3), Cutting (X4), Timber tract (X5), Price (X6), Place (X7), Marketing Expenses (X8) significant influences on the sales volume.

The 4Ps of marketing influence 50\% obtained from the type of product and its attributes and price. The type of product and its attributes play an important role in attracting prospective timber buyers related to purchasing decisions. It can be seen from the transaction data that the type with attributes in the form of a Roundwood assortment with size $4 \mathrm{~cm}$ and above, the timber quality no. 4 and above, cutting types a and b, the tract of timber with the highest volume influences significantly on the sales volume. On the other hand, place and marketing expenses have no significant effect on the sales volume because buyers directly buy to the location by placing an order in advance. Ordering is relatively easy through the application platform to order timber. In this case, buyers are willing to reach the location even though in remote areas.

\section{REFERENCES}

[1] Arifin, Syamsul."MARKETING PENDIDIKAN."Tadris: Jurnal Penelitian dan Pemikiran Pendidikan Islam 14, no. 1 (2020): $112-123$.

[2] Assauri, Sofjan. "Manajemen operasi produksi." Jakarta: PT Raja Grafindo Persada (2016).

[3] Charles Lamb, W.et.al. 2001. Pemasaran. Edisi Pertama, Jakarta. Salemba Empat.

[4] Departemen Kehutanan. "Sifat dan Kegunaan 120 Jenis Kayu Perdagangan Indonesia”. http://www.dephut.go.id (2010)

[5] Fanani, Zaenal, Satrijo Budiwibowo, \& Juli Murwani. (2017). Hubungan Strategi Pemasaran Kayu Jati terhadap Peningkatan Volume Penjualan pada Kantor Komersial Kayu Wilayah Madiun. The 9th FIPA: Forum Ilmiah Pendidikan. Vol.5(1):450-460.

[6] Henderson, J.E., I.A. Munn, G.Perez-Verdin and D.L. Grebner. 2008. Forestry in Mississippi: the impact of the forest products industry on the post-Katrina Mississippi economy - an output analysis. Forest and Wildlife Research Center, Research Bulletin FO374, Mississippi State University. 31pp.

[7] Indrawati, Ph D. "Metode Penelitian Manajemen dan Bisnis Konvergensi Teknologi Komunikasi dan Informasi." Bandung: PT Refika Aditama (2015).

[8] Kotler, P., and Keller, K.L. (2016). Manajemen Pemasaran. Jakarta: Erlangga.

[9] Leskinen, P.; Kangas, J. Modelling and simulation of timber prices for forest planning calculations. Scand. J. For. Res. 1998, 13, 469-476. [CrossRef]

[10] Leskien, P.; Kangas, J. Modelling future timber price development by using expert judgments and time series analysis: Silva Fennica. Silva Fenn. 2001, 35, 93-102.

[11] Malau, Harman. "Manajemen Pemasaran; Teori dan aplikasi pemasaran era tradisional sampai era modernisasi global." (2017). 
DOI: $\underline{10.51386 / 25815946 / \mathrm{ijsms}-\mathrm{v} 4 \mathrm{i} 4 \mathrm{p} 114}$

Volume: 4 Issue: 4

July to August 2021

https://www.ijjsmsjournal.org

[12] Marek Giergiczny \& Natalia Nehrebecka \& Tomasz Zylicz, 2015. "Selling timber in Poland," Working Papers 2015-34, Faculty of Economic Sciences, University of Warsaw.

[13] McClave T. James and Benson P. George. 2017. Statistics for Business and Economics, 13th Edition. Pearson

[14] Mississippi State University, Cooperative Extension Service. 2009. 2009 harvest of forest products, forest economics. Report MTN23C, February 2010. 8 pp. Also available at http://www.msucares.com/forestry/economics/reports.

[15] Pietersz, J. H. 2003. Ilmu Ukur Kayu dan Sortimen. Jurusan Kehutanan Fakultas Pertanian Universitas Pattimura. Ambon.

[16] Prasetyo, Irawan. "perbedaan Penggunaan Serbuk Gergaji dari Kayu Keras dan Kayu Lunak Sebagai Media Tanam Terhadap Pertumbuhan Jamur Tiram Putih (pleurotus ostreatus)." PhD diss., Universitas Islam Negari Alauddin makassar, 2015.

[17] Ratnaningsih,et al.(2008). Analisa Pemilihan Jenis Kayu Unggulan Sebagai Bahan Baku Dasar Untuk Pembuatan Mebel. Tersedia dari Proquest Dissertation \& Theses Database. (UMI No. 173208).

[18] Rangkuti, Freddy. "Teknik Membedah Kasus Bisnis." (2019).

[19] Schiffman, L. G., Kanuk, L. L., \& Hansen, H. (2012). Consumer Behavior An European Outlook (2nd ed.). Harlow: Pearson Education.

[20] Spetic, W. C., Kozak, R. A., \& Vidal, N. G. (2016). Critical factors of competitiveness for the British Columbia secondary wood products industry. Bioproducts Business, 1(2), 13-31.

[21] Sugiri, Saptahari \& Alamsyah, Eka \& Usman, Arie. (2016). Potential of Reinforced Indonesian Glulam Beams Using Grade I (Bengkirai), Grade II (Kamper), Grade III (Nyatoh) Woods for Use in Structural Wood Design. Journal of Engineering and Technological Sciences. 48. 150-158. 10.5614/j.eng.technol.sci.2016.48.2.2.

[22] Sugiyono, Prof. Dr. 2010. Metode Penelitian Kuantitatif Kualitatif dan R\&D. Bandung: CV. Alfabeta.

[23] Sukmawan, Dhida Praja. 2010. Strategi Pemasaran Katu Bundar Jati (Tectona grandis) Pada Perum Perhutani KBM Pemasaran Kayu I Cirebon Jawa Barat. Jurusan Agribisnis Fakultas Ekonomi dan Manajemen IPB. Bogor.

[24] Swastha, Basu. "Azas-Azas Marketing (cetakan ketujuh)." Yogyakarta: Liberty (2009).

[25] Tjiptono, Fandy. "Strategi pemasaran." (2019).

[26] Wirjomartono. “Konstruksi Kayu”. Yogyakarta: Universitas Gajah Mada Press. (2009)

[27] Winarto, Bambang. Kamus Kehutanan. PT Penerbit IPB Press, 2021.

[28] Vendi, Susanto. 2020. "Ekspor kayu olahan Indonesia sepanjang tahun 2019 turun 4\%”, https://industri.kontan.co.id/news/eksporkayu-olahan-indonesia-sepanjang-tahun-2019-turun-4-1 ?page=2, accessed 20 Jan.2020 